\title{
PENGARUH STRUKTUR MODAL TERHADAP NILAI PERUSAHAAN DENGAN PERTUMBUHAN PERUSAHAAN SEBAGAI VARIABEL MODERATING
}

\author{
Rohaelis Nuraisiah.SE.,MM.,Mak \\ rohaelisnuaraisiah@unbaja.ac.id \\ Fakultas Ekonomi dan Bisnis Universitas Banten Jaya \\ Prodi Kewirausahaan
}

\begin{abstract}
ABSTRAK
Penelitian ini bertujuan untuk menguji dan menemukan bukti empiris mengenai: (1) ada pengaruh positif struktur modal terhadap nilai perusahaan, (2) ada pengaruh positif pertumbuhan perusahaan terhadap nilai perusahaan, dan (3) ada pengaruh positif struktur modal terhadap nilai perusahaan dengan pertumbuhan perusahaan sebagai variabel moderating. Sampel yang digunakan dalam penelitian ini adalah perusahaan manufaktur yang terdaftar di Bursa Efek Indonesia selama 4 tahun perioda observasi (2008-2011). Total sampel sebanyak 19 perusahaan. Data dikumpulkan menggunakan metoda purposive sampling. Hasil berdasarkan moderated regression analysis (MRA) menunjukkan bahwa: (1) struktur modal tidak berpengaruh terhadap nilai perusahaan, (2) pertumbuhan perusahaan tidak berpengaruh terhadap nilai perusahaan, dan (3) struktur modal tidak berpengaruh terhadap nilai perusahaan dengan pertumbuhan perusahaan sebagai variabel moderating. Jadi, hipotesis penelitian tidak didukung secara empiris.

Kata Kunci: Struktur Modal, Pertumbuhan Perusahaan, dan Nilai Perusahaan.
\end{abstract}

\section{PENDAHULUAN}

\section{A. LATAR BELAKANG PENELITIAN}

Perusahaan didirikan dengan tujuan untuk memakmurkan pemilik perusahaan atau pemegang saham. Tujuan ini dapat diwujudkan dengan memaksimumkan nilai perusahaan dengan asumsi bahwa pemilik perusahaan atau pemegang saham akan makmur jika kekayaannya meningkat. Meningkatnya kekayaan dapat dilihat dari semakin meningkatnya harga saham yang berarti juga nilai perusahaan meningkat. Masalah struktur modal merupakan masalah yang sangat penting bagi setiap perusahaan, karena baik buruknya struktur modal akan mempunyai efek yang langsung terhadap posisi keuangan perusahaan. Suatu perusahaan yang mempunyai struktur modal yang tidak baik dan mempunyai hutang yang sangat besar akan memberikan beban berat kepada perusahaan yang bersangkutan (Riyanto, 2001). Penggunaan kebijakan hutang bisa digunakan untuk menciptakan nilai perusahaan yang diinginkan, namun kebijakan hutang juga tergantung dari pertumbuhan perusahaan yang juga terkait dengan ukuran perusahaan. Artinya perusahaan yang besar dan memiliki tingkat pertumbuhan perusahaan yang baik relatif lebih mudah untuk mengakses ke pasar modal. Kemudahan ini mengindikasikan bahwa perusahaan besar relatif mudah memenuhi sumber dana dari hutang melalui pasar modal, perusahaan yang memiliki tingkat pertumbuhan perusahaan yang baik 2 menunjukkan kemampuan perusahaan untuk membayar bunga hutang jika menggunakan hutang untuk dana operasional perusahaan tersebut. Brigham dan Houston (2009) mengartikan bahwa struktur 
keuangan (financial leverage) merupakan cara aktiva-aktiva perusahaan dibelanjai/dibiayai. Hal ini seluruhnya merupakan bagian kanan neraca, sedangkan struktur modal (capital structure) merupakan pembiayaan pembelanjaan permanen perusahaan, yang terutama berupa hutang jangka panjang, saham preferen/prioritas dan modal saham biasa, tetapi tidak semua masuk kredit jangka pendek. Jadi struktur modal dalam suatu perusahaan hanya sebagian dari struktur keuangannya. Prinsip manajemen perusahaan baik dalam memperoleh maupun menggunakan dana harus didasarkan pada efisiensi dan efektifitas. Efisiensi penggunaan dana berarti bahwa berapapun dana yang ditanamkan dalam aktiva harus dapat digunakan seefisien mungkin untuk menghasilkan tingkat keuntungan investasi yang maksimal. Oleh karena itu, pengalokasian dana harus didasarkan pada perencanaan yang tepat sehingga dana yang menganggur menjadi kecil. Efisiensi penggunaan dana secara langsung dan tidak langsung akan menentukan besar kecilnya keuntungan yang dihasilkan dari investasi. Manajer keuangan harus bijaksana dalam menjalankan fungsi penggunaan dana yang selalu dituntut untuk mencari alternatif investasi kemudian dianalisis dan hasil analisis tersebut harus dapat diambil keputusan alternatif mana yang akan dipilih. Dengan kata lain, manajer harus mengambil keputusan investasi dengan tepat. 3 Menurut Machfoedz (1996) pertumbuhan (growth) adalah seberapa jauh perusahaan menempatkan diri dalam sistem ekonomi secara keseluruhan atau sistem ekonomi untuk industri yang sama. Pada umumnya, perusahaan yang tumbuh dengan cepat memperoleh hasil positif dalam artian pemantapan posisi di dunia persaingan usaha, menikmati penjualan yang meningkat secara signifikan dan diiringi oleh adanya peningkatan pangsa pasar. Perusahaan yang tumbuh cepat juga menikmati keuntungan dari citra positif yang diperoleh, akan tetapi perusahaan harus ekstra hatihati karena kesuksesan yang diperoleh menyebabkan perusahaan rentan terhadap isuisu negatif. Pertumbuhan cepat juga memaksa sumber daya manusia yang dimiliki secara optimal memberikan kontribusinya. Menurut Susanto (1997) agar pertumbuhan cepat tidak memiliki arti pertumbuhan biaya yang kurang terkendali, maka dalam mengelola pertumbuhan, perusahaan harus memiliki pengendalian operasi dengan penekanan pada pengendalian biaya. Fama dan French (1998) berpendapat bahwa optimalisasi perusahaan yang merupakan tujuan perusahaan dapat dicapai melalui fungsi manajemen keuangan, dimana satu keputusan keuangan yang diambil akan mempengaruhi keputusan keuangan lainnya dan berdampak pada nilai perusahaan. Menurut Brigham dan Houston (2009) beberapa faktor yang umumnya dipertimbangkan dalam mengambil keputusan mengenai nilai perusahaan yaitu stabilitas penjualan, struktur aktiva, leverage operasi, tingkat pertumbuhan, profitabilitas, pajak, pengendalian, sikap manajemen, sikap pemberi pinjaman, perusahaan penilai kredibilitas, kondisi pasar, kondisi internal perusahaan, dan 4 fleksibilitas keuangan. Bagi Chen (2002) faktor yang dapat mempengaruhi nilai perusahaan, diantaranya adalah capital structure, profitability, tax rate, capital expenditure, dan firm size. Riyanto (2001) menyebutkan ada tingkat bunga stabilitas dari earnings, susunan dari aktiva, kadar risiko dari aktiva, besarnya jumlah modal yang dibutuhkan, keadaan pasar modal, sifat manajemen, dan besarnya suatu perusahaan dalam menentukan nilai perusahaan. Soliha dan Taswan (2002) menemukan bukti bahwa kebijakan hutang berpengaruh positif namun tidak signifikan terhadap nilai perusahaan. Hasil penelitian ini konsisten dengan temuan Modigliani dan Miller (1963) bahwa dengan memasukkan pajak penghasilan perusahaan, maka penggunaan hutang akan meningkatkan nilai perusahaan. Berdasarkan penelitian Safrida (2008) bahwa struktur modal dan pertumbuhan perusahaan secara bersama-sama berpengaruh negatif dan signifikan terhadap nilai 
perusahaan. Hal ini berarti bahwa penggunaan hutang sebagai sumber pendanaan perusahaan dan penurunan perubahan total aktiva perusahaan akan meningkatkan harga perlembar saham terhadap ekuitas perlembar saham ketika perusahaan mengurangi penggunaan hutang dan meskipun penurunan perubahan total aktiva perusahaan, perusahaan masih mampu memperoleh dana di pasar modal untuk melakukan investasi sehingga nilai pasar perlembar saham terhadap ekuitas perlembar saham akan meningkat.

\section{RUMUSAN MASALAH}

Berdasarkan beberapa hasil penelitian yang dilakukan oleh beberapa peneliti sebelumnya, peneliti bermaksud untuk mendapatkan bukti secara empiris mengenai: 1 . Apakah ada pengaruh positif struktur modal terhadap nilai perusahaan. 2. Apakah ada pengaruh positif pertumbuhan perusahaan terhadap nilai perusahaan. 3. Apakah ada pengaruh positif struktur modal terhadap nilai perusahaan dengan pertumbuhan perusahaan sebagai variabel moderating.

\section{TUJUAN PENELITIAN}

Penelitian ini bertujuan untuk menguji dan menemukan bukti empiris mengenai: 1. Ada pengaruh positif struktur modal terhadap nilai perusahaan. 2. Ada pengaruh positif pertumbuhan perusahaan terhadap nilai perusahaan. 3. Ada pengaruh positif struktur modal terhadap nilai perusahaan dengan pertumbuhan perusahaan sebagai variabel moderating.

\section{MANFAAT PENELITIAN}

Hasil penelitian ini diharapkan dapat memberi manfaat penelitian, yaitu: 1. Memberikan bukti empiris mengenai: a. Ada pengaruh positif struktur modal terhadap nilai perusahaan. $b$. Ada pengaruh positif pertumbuhan perusahaan terhadap nilai perusahaan. $6 \mathrm{c}$. Ada pengaruh positif struktur modal terhadap nilai perusahaan dengan pertumbuhan perusahaan sebagai variabel moderating. 2. Dengan hasil yang diperoleh diharapkan para pemakai informasi struktur modal, pertumbuhan perusahaan, dan nilai perusahaan mendapat informasi untuk pengambilan keputusan.

\section{KONTRIBUSI PENELITIAN}

Penelitian mengenai pengaruh struktur modal dan pertumbuhan perusahaan terhadap nilai perusahaan telah banyak dilakukan. Namun penelitian yang lebih mendalam tentang struktur modal dan pertumbuhan perusahaan dalam memprediksi nilai perusahaan belum banyak dilakukan terutama di Indonesia. Pentingnya penelitian tentang pengaruh struktur modal terhadap nilai perusahaan dengan pertumbuhan perusahaan sebagai variabel moderating untuk perusahaan manufaktur didasari oleh beberapa alasan. Pertama, masih kurangnya penelitian yang menguji pengaruh struktur modal terhadap nilai perusahaan dengan pertumbuhan perusahaan sebagai variabel moderating. Kedua, hasil dari penelitian sebelumnya mengenai pengaruh struktur modal dan pertumbuhan perusahaan terhadap nilai perusahaan tidak konsisten. Perbedaan penelitian ini dengan penelitian-penelitian sebelumnya adalah penelitian ini mencoba meneliti pengaruh struktur modal terhadap nilai perusahaan dengan pertumbuhan perusahaan sebagai variabel moderating. Hal ini sekaligus juga merupakan kontribusi penelitian.

\section{LANDASAN TEORITIS DAN PENGEMBANGAN HIPOTESIS TEORI SIGNAL}

Struktur modal dengan tingkat leverage yang tinggi digunakan sebagai sinyal untuk membedakan perusahaan yang baik dan yang buruk. Hanya perusahaan yang sehat 
dan kuat yang dapat berhutang dengan menanggung risikonya. Oleh karena itu, untuk meminimalkan biaya informasi dari pelepasan saham, maka suatu perusahaan lebih menyukai menggunakan hutang daripada ekuitas jika perusahaan tampak undervalued, dan menggunakan ekuitas dari pada hutang jika perusahaan tampak overvalued. Myers dan Majluf (1984) memiliki pandangan bahwa ada informasi asimetrik yang terjadi antara manajer perusahaan dan investor. Biaya akibat informasi asimetrik meningkat ketika manajer dalam perusahaan memiliki pengetahuan yang superior mengenai distribusi risiko dan tingkat pengembalian proyek-proyek investasi, dibandingkan dengan investor di luar yang baru. Selanjutnya manajer perusahaan memaksimalkan nilai yang sesungguhnya dari klaim pemegang saham saat ini.

\section{METODA PENELITIAN}

\section{POPULASI DAN SAMPEL PENELITIAN}

Penentuan populasi dalam penelitian ini adalah seluruh perusahaan yang terdaftar di Bursa Efek Indonesia selama tahun 2008-2011. Penentuan sampel dalam penelitian ini berdasarkan pada metoda purposive sampling, dimana sampel dipilih berdasarkan pada kriteria tertentu. Adapun kriteria yang digunakan untuk memilih sampel adalah sebagai berikut: 1. Perusahaan manufaktur yang terdaftar di Bursa Efek Indonesia. 2. Perusahaan manufaktur yang menerbitkan laporan keuangan dari tahun 2008- 2011. 3. Perusahaan manufaktur yang memiliki nilai ekuitas positif dalam laporan keuangan perioda penelitian dari tahun 2008-2010. 4. Perusahaan manufaktur yang memiliki nilai perubahan aktiva yang positif pada perioda penelitian dari tahun 2008-2010. Berdasarkan kriteria tersebut, jumlah sampel yang digunakan dalam penelitian ini sebanyak 19 perusahaan perioda 2008-2011 terdapat pada tabel 1 (dalam lampiran). B. SUMBER DATA Data yang digunakan dalam penelitian ini berupa data sekunder dan pool, yang terdiri dari: 21 a. Perusahaan manufaktur yang terdaftar di BEI pada tahun 2008-2011. b. Data laporan keuangan publikasian tahunan (annual report), yang terdiri dari neraca, laporan laba rugi, dan laporan arus kas selama tahun 2008 sampai dengan tahun 2011. Data tersebut diperoleh dengan cara studi dokumentasi yang berasal dari Indonesian Capital Market Directory (ICMD) dan IDX perioda tahun 2008- 2011.

\section{HASIL EMPIRIS}

Dari hasil dan analisis dari data yang digunakan dalam penelitian.

\section{UJI MODEL REGRESI Uji F}

Metode ini digunakan untuk mengetahui kelayakan model, apakah permodelan yang dibangun memenuhi kriteria fit atau tidak. Model regresi dikatakan fit apabila tingkat probabilitas F-statistik lebih kecil dari 0,05. Berdasarkan hasil perhitungan diperoleh nilai $\mathrm{F}$ hitung seperti disajikan pada tabel 2 (dalam lampiran). Dari tabel 2 nilai probabilitas F-statistik $(0,844)>\alpha(0,05)$, hal ini berarti bahwa model regresi yang dibangun tidak memenuhi kriteria fit model. Model regresi yang dibangun kurang layak digunakan untuk memprediksi variabel nilai perusahaan.

\section{UJI ASUMSI KLASIK.}

Sebelum dilakukan pengujian dengan menggunakan moderated regression analysis (MRA), dilakukan pengujian asumsi klasik. Hal ini dimaksudkan agar model regresi dapat menghasilkan penduga (estimator) yang tidak bias. Model regresi akan menghasilkan penduga yang tidak bias jika memenuhi asumsi 
klasik, antara lain normalitas data, bebas multikolinieritas, bebas autokorelasi, dan bebas heteroskedastisitas.

\section{HASIL PENGUJIAN HIPOTESIS}

a) Pengaruh Struktur Modal terhadap Nilai Perusahaan Berdasarkan tabel 3 (dalam lampiran), nilai signifikansi yang diperoleh untuk Debt to Equity Ratio (DER) terhadap Market to Book Ratio (MBR) adalah 0,395. Maka dapat disimpulkan bahwa H1 ditolak, karena nilai signifikansi yang diperoleh $(0,395)$ lebih besar daripada taraf signifikansi $(0,05)$ artinya struktur modal tidak mempunyai pengaruh terhadap nilai perusahaan.

b) Pengaruh Pertumbuhan Perusahaan terhadap Nilai Perusahaan Berdasarkan tabel 3 (dalam lampiran), nilai signifikansi yang diperoleh untuk Perubahan Total Aktiva (PTA) terhadap Market to Book Ratio (MBR) adalah 0,679. Maka dapat disimpulkan bahwa $\mathrm{H} 2$ ditolak, karena nilai signifikansi yang diperoleh $28(0,679)$ lebih besar daripada taraf signifikansi $(0,05)$ artinya pertumbuhan perusahaan tidak mempunyai pengaruh terhadap nilai perusahaan.

c) Pengaruh Struktur Modal terhadap Nilai Perusahaan dengan Pertumbuhan Perusahaan sebagai Variabel Moderating Berdasarkan tabel 3 (dalam lampiran), nilai signifikansi yang diperoleh untuk Debt to Equity Ratio (DER) dan Perubahan Total Aktiva (PTA) terhadap Market to Book Ratio (MBR) adalah 0,532. Disimpulkan bahwa H3 ditolak, karena nilai signifikansi $(0,532)$ yang diperoleh lebih besar daripada taraf signifikansi $(0,05)$. Hal ini berarti dengan tingkat kepercayaan 95\% dapat disimpulkan bahwa struktur modal tidak mempunyai pengaruh terhadap nilai perusahaan dengan pertumbuhan perusahaan sebagai variabel moderating.

\section{PEMBAHASAN}

Hasil penelitian ini menunjukkan bahwa struktur modal tidak mempunyai pengaruh terhadap nilai perusahaan yang dapat dilihat dari nilai signifikansi yaitu sebesar 0,395. Hasil penelitian ini terbukti menolak hipotesis $1(\mathrm{H} 1)$ yang menyatakan bahwa struktur modal berpengaruh positif terhadap nilai perusahaan. Hasil penelitian ini konsisten dengan penelitian Soliha dan Taswan (2002), dan Sulistiono (2010). Hasil penelitian ini tidak konsisten dengan penelitian Prasetiadi (2007), dan Chotimah (2007). Hasil penelitian ini menunjukkan bahwa pertumbuhan perusahaan tidak mempunyai pengaruh terhadap nilai perusahaan yang dapat dilihat dari nilai 29 signifikansi yaitu sebesar 0,679. Hasil penelitian ini terbukti menolak hipotesis $2(\mathrm{H} 2)$ yang menyatakan bahwa pertumbuhan perusahaan berpengaruh positif terhadap nilai perusahaan. Hasil penelitian ini konsisten dengan temuan sebelumnya yang telah dilakukan oleh Asba (2009). Hasil penelitian ini tidak konsisten dengan Sriwardany (2006), Burhanuddin (2009), dan Atmojo (2010). Hasil penelitian ini menunjukkan bahwa struktur modal tidak berpengaruh terhadap nilai perusahaan dengan pertumbuhan perusahaan sebagai variabel moderating yang dapat dilihat dari nilai signifikansi yaitu sebesar 0,532 . Hasil penelitian ini terbukti menolak hipotesis 3 (H3) yang menyatakan bahwa struktur modal berpengaruh terhadap nilai perusahaan dengan pertumbuhan perusahaan sebagai variabel moderating. Hasil penelitian ini konsisten dengan penelitian 
Megarini (2003). Hasil penelitian ini tidak konsisten dengan penelitian Sugihen (2003), Safrida (2008), dan Nasution (2009). Terdapat beberapa kemungkinan untuk menjelaskan hasil tersebut, yaitu: 1. Sampel penelitian ini hanya menggunakan 19 perusahaan manufaktur dari seluruh perusahaan manufaktur yang listing di BEI sehingga hasilnya tidak menggambarkan atau mewakili populasi secara keseluruhan. 2. Pada perioda penelitian yaitu 2008-2011 telah terjadi krisis Amerika Serikat yang memicu krisis perekonomian global mengakibatkan terguncangnya pasar modal dan indikator lain di Indonesia.

\section{PENUTUP}

Bab ini berisi tentang simpulan hasil penelitian yang akan mendiskusikan ringkasan hasil penelitian dan memberikan beberapa saran untuk pihak-pihak yang mungkin dapat mengambil manfaat dari hasil penelitian ini. Bab ini juga membahas tentang keterbatasan penelitian yang dapat membuka peluang bagi peneliti lain untuk mengembangkan penelitian ini lebih lanjut.

\section{SIMPULAN}

Penelitian ini bertujuan untuk menguji dan menemukan bukti empiris mengenai:

1. Terdapat pengaruh yang signifikan struktur modal terhadap nilai perusahaan.

2. Terdapat pengaruh yang signifikan pertumbuhan perusahaan terhadap nilai perusahaan.

3. Terdapat pengaruh yang signifikan struktur modal terhadap nilai perusahaan dengan pertumbuhan perusahaan sebagai variabel moderating. Sampel yang digunakan dalam penelitian ini diambil dari tahun 2008 sampai tahun 2011 untuk perusahaan-perusahaan manufaktur yang terdaftar di BEI. Penelitian ini tidak mendukung hipotesis alternatif yang diajukan, yaitu:

1. Struktur modal tidak berpengaruh terhadap nilai perusahaan.

2. Pertumbuhan perusahaan tidak berpengaruh terhadap nilai perusahaan.

3. Struktur modal tidak berpengaruh terhadap nilai perusahaan dengan pertumbuhan perusahaan sebagai variabel moderating.

\section{KETERBATASAN PENELITIAN}

Peneliti menyadari adanya beberapa keterbatasan yang mungkin mempengaruhi hasil sehingga hasil penelitian ini tidak dapat digeneralisasi. Beberapa keterbatasan dalam penelitian ini antara lain adalah:

1. Jumlah sampel tidak dilakukan secara random, tetapi mensyaratkan kriteriakriteria tertentu (purposive sampling), yaitu dengan membatasi kriteria sampel hanya untuk perusahaan manufaktur. Karena itu hasil penelitian ini tidak dapat digeneralisasi untuk sektor diluar manufaktur.

2. Jumlah perusahaan yang menjadi sampel penelitian relatif sedikit, hanya 19 perusahaan selama 4 tahun (2008-2011). Sedikitnya sampel ini disebabkan karena beberapa kendala antara lain ketidaklengkapan laporan keuangan perusahaan manufaktur secara keseluruhan. Hal ini menyebabkan beberapa perusahaan dikeluarkan dari sampel karena tidak memenuhi kriteria 
pemilihan sampel yang telah ditentukan. 3. Penelitian ini hanya menguji pertumbuhan perusahaan sebagai variabel moderating pada hubungan antara struktur modal dengan nilai perusahaan.

\section{IMPLIKASI PENELITIAN}

Penelitian ini diharapkan dapat memberikan ide untuk pengembangan penelitian selanjutnya. Berdasarkan keterbatasan yang ada, penelitian selanjutnya dapat mempertimbangkan hal-hal berikut ini:

1. Jumlah sampel dilakukan secara acak/random, dan tidak mensyaratkan kriteriakriteria tertentu. Sampel penelitian tidak hanya untuk perusahaan manufaktur, tetapi juga perusahaan non-manufaktur, sehingga penelitian ini diharapkan memberikan hasil yang dapat digeneralisasi keseluruhan perusahaan di Indonesia.

2. Jangka waktu riset dapat diperpanjang (misalnya selama 10 tahun) dan dengan jumlah sampel perusahaan yang lebih besar dan lebih beragam. Perpanjangan perioda penelitian dan penambahan jumlah sampel mungkin akan memberikan hasil yang lebih baik dalam mengestimasi nilai perusahaan.

3. Penelitian selanjutnya dapat menambah variabel moderating yang lain, misalnya kepemilikan manajerial, ukuran perusahaan, dan perubahan nilai valuta asing. Penambahan variabel moderating akan memberikan pemahaman yang semakin lengkap tentang faktor-faktor yang mempengaruhi struktur modal dan pertumbuhan perusahaan dengan nilai perusahaan.

\section{DAFTAR PUSTAKA}

Asba, S. (2009). Pengaruh Corporate Governance, Asset dan Growth terhadap Kinerja Pasar. Skripsi. Jakarta: Universitas Gunadarma.

Atmojo, C. R. (2010). Pengaruh Corporate Governance, Ukuran Perusahaan dan Pertumbuhan Perusahaan, dan Profitability terhadap Nilai Perusahaan. Skripsi. Surabaya: Universitas Airlangga.

Brigham, E. F., dan J. F. Houston. (2009). Fundamentals of Financial Management. 6th Edition. South Western, Cengage Learning. Burhanuddin. (2009). Pengaruh Earnings Per Share, Pertumbuhan Perusahaan, dan Tingkat Suku Bunga terhadap Harga Saham. Skripsi. Palu: Universitas Muhammadiyah Palu.

Chen, K. (2002). The Influence of Capital Structure on Company Value with Different Growth Opportunities. Paper of EFMA Meeting. Swiss.

Chotimah, S. (2007). Analisis Pengaruh Perubahan Struktur Modal terhadap Perubahan Nilai Perusahaan. Skripsi. Surakarta: Universitas Muhammadiyah Surakarta.

Fama, E. F., dan K. R. French. (1998). Taxes, Financing Decision, and Firm Value. The Journal of Finance LIII (3): 819-843. Ghozali, I. (2011). Aplikasi Analisis Multivariate dengan Program SPSS. Badan Penerbit Universitas Diponegoro, Semarang.

Gujarati, D. N. (2003). Basic Econometrics. 4th edition. McGraw-Hill International Edition, Economics Series. Hasnawati, S. (2005). Implikasi keputusan Investasi, Pendanaan, dan Dividen terhadap Nilai Perusahaan Perusahaan Publik di Bursa Efek Jakarta. Usahawan XXXIX (09): 33-41.

Helfert, E. A. (1997). Teknik Analisis Keuangan. Terjemahan: Herman Wibowo. Edisi Kedelapan. Jakarta: Erlangga. 
Indriantoro, N., dan B. Supomo. (2002). Metodologi Penelitian Bisnis Untuk Akuntansi dan Manajemen. Edisi Pertama. Yogyakarta: BPFE. 34

Machfoedz, M. (1996). Akuntansi Manajemen Perencanaan dan Pembuatan Keputusan Jangka Pendek. Edisi Kelima. Buku 1. Yogyakarta: STIE-WIDYA WIWAHA.

Megarini, L. S. (2003). Analisis Pengaruh Kinerja Keuangan terhadap Perubahan Harga Saham pada Perusahaan Manufaktur yang Terdaftar di BEI. Skripsi. Surakarta: Universitas Sebelas Maret.

Meythi. (2006). Pengaruh Arus Kas Operasi terhadap Harga Saham dengan Persistensi Laba sebagai Variabel Intervening. Simposium Nasional Akuntansi 9. Padang. 23-36 Agustus.

Modigliani, F., dan M. H. Miller. (1963). Corporate Income Taxes and The Cost of Capital: A Correction. The American Economic Review 53 (3): 433-443.

Myers, S., dan N. Majluf. (1984). Corporate Financing an Investment Decision when Firms have Information Investors Do no Have. Journal of Finance Economics 13: 187-221.

Nasution, B. A. (2009). Pengaruh Struktur Modal, Biaya Ekuitas (Cost of Equity) dan Pertumbuhan Perusahaan terhadap Nilai Perusahaan dengan Klasifikasi Perusahaan dan Kepemilikan Asing sebagai Variabel Moderating pada Perusahaan Lembaga Keuangan yang Terdaftar di BEI. Tesis. Magister Sains. Medan: Universitas Sumatera Utara.

Prasetiadi. R. (2007). Pengaruh Struktur Modal terhadap Nilai Perusahaan. Tesis. Jakarta: Universitas Indonesia. 